\title{
Class effect of pharmacotherapy in bipolar disorder: fact or misbelief?
}

\author{
Konstantinos N Fountoulakis ${ }^{1 *}$, Xenia Gonda ${ }^{2,3}$, Eduard Vieta ${ }^{4}$ and Zoltan Rihmer ${ }^{3}$
}

\begin{abstract}
Background: Anecdotal reports suggests that most clinicians treat medications as belonging to a class with regard to all therapeutic indications; this means that the whole 'class' of drugs is considered to possesses a specific therapeutic action. The present article explores the possible existence of a true 'class effect' for agents available for the treatment of bipolar disorder.

Methods: We reviewed the available treatment data from randomized controlled trials (RCTs) and explored 16 'agent class'/'treatment issue' cases for bipolar disorder. Four classes of agents were examined: first-generation antipsychotics (FGAs), second-generation antipsychotics (SGAs), antiepileptics and antidepressants, with respect to their efficacy on four treatment issues of bipolar disorder (BD) (acute mania, acute bipolar depression, maintenance against mania, maintenance against depression).
\end{abstract}

Results: From the 16 'agent class'/' treatment issue' cases, only 3 possible class effects were detected, and they all concerned acute mania and antipsychotics. Four effect cases have not been adequately studied (FGAs against acute bipolar depression and in maintenance protection from depression, and antidepressants against acute mania and protection from mania) and they all concern treatment cases with a high risk of switching to the opposite pole, thus research in these areas is poor. There is no 'class effect' at all concerning antiepileptics.

Conclusions: The available data suggest that a 'class effect' is the exception rather than the rule in the treatment of BD. However, the possible presence of a 'class effect' concept discourages clinicians from continued scientific training and reading. Focused educational intervention might be necessary to change this attitude.

\section{Background}

In the last decade there were important developments in our understanding of bipolar disorder (BD), as well as its treatment. From a historical point of view, since Hippocrates from antiquity to Emil Kraepelin in the early 20th century, manic depressive illness has been established as a nosological entity (and separate from schizophrenia) on the basis of heredity, longitudinal follow-up and a supposed favorable outcome. However, recently there was important insight into the illness with the description and definition of subtypes (BD-I to BD-VI) [1-3].

This dramatically changed the perceived epidemiology of the disorder. Although earlier studies suggested that the classic manic depressive psychosis had a prevalence of around $1 \%(0.4 \%$ to $1.6 \%)$, today we know that the true

\footnotetext{
* Correspondence: kfount@med.auth.gr

'Third Department of Psychiatry, School of Medicine, Aristotle University of Thessaloniki, Greece

Full list of author information is available at the end of the article
}

prevalence depends on the definition, and with the inclusion of subthreshold bipolar cases, pseudounipolar patients and personality disorders (PDs), especially 'borderline personality disorder' under the umbrella of the 'bipolar spectrum', the combined prevalence rate is up to $3.7 \%$, with BD-II being the most prevalent subtype [4-6].

Similarly, our knowledge and understanding of treatment has progressed, largely following our understanding of the clinical picture. The first dramatic conclusion was that the outcome of bipolar illness is not favorable as Kraepelin had determined, but rather suboptimal and is strongly related to younger age of onset and to alcohol and substance abuse. Following this fact, the World Health Organization (WHO) has recently ranked bipolar disorder among the 10 most disabling medical conditions worldwide [7].

Today we know that the treatment of bipolar illness is complex and full of caveats for the clinician [8-11], with some aspects of the disorder being rather refractory to

\section{() Biomed Central}


treatment. One widespread concept among clinicians is that of the so-called 'class effect'. As most pharmaceutical agents belong to a 'class' usually on the basis of their primary therapeutic labeling (for example, antipsychotics, anticonvulsants, antidepressants and so on), it seems that clinicians use them according to the 'class' they belong rather than on the basis of the individual substance and its properties. This means that the whole 'class' of drugs is considered to possesses a specific therapeutic action that in some cases has been proven only for a few of its members or even only for a single one. An example in the case of BD could be that all 'antiepileptics' are also 'mood stabilizers'. Clinicians and researchers seem to treat agents in a 'class' way, by, for example, suggesting that antidepressants do not work in bipolar depression in spite of the fact that negative data exist only for a few of them while positive data might exist for fluoxetine.

If such a situation exists, and patients usually receive treatment according to a 'class effect', it has huge implications for public health and also for the overall cost of mental disorders, and especially for bipolar disorder. The 'class effect' provides the clinician with fast and simple rules to determine treatment, but in the case of bipolar disorder it might provide the clinician with oversimplified and false rules, and might result in a significant proportion of patients receiving the wrong treatment.

The present work aims to determine whether such 'class effects' are present in bipolar disorder. On the basis of available evidence, several reviews and metaanalysis papers [12-16] developed tables concerning the efficacy of various agents in the different faces and facets of bipolar illness (Table 1). The question was whether these tabulated data support or call into question the presence of a 'class effect' for the treatment of bipolar disorder.

\section{Methods}

We reviewed the available treatment data from randomized controlled trials (RCTs). These treatment datasets have already been published previously [12-16], so only minor additions were necessary. Four classes of agents were examined: first-generation antipsychotics (FGAs), second-generation antipsychotics (SGAs), antiepileptics and antidepressants, with respect to their efficacy on four treatment issues of BD (acute mania, acute bipolar depression, maintenance against mania, maintenance against depression). This led to a $4 \times 4$ crosstabulation with 16 'agent class'/'treatment issue' cases.

Although such tables already exist in previous works, we created a new one on the basis of a fresh look at the available data. In spite of a 'general acceptance' of treatment options for bipolar disorder, the evidence shows a much different picture. Thus, a review of the literature was judged to be necessary. If the opposite were the, case the table would rely on arbitrary opinion and could be misleading.

\section{Results}

\section{Effective treatments for bipolar disorder}

Valproate has proven efficacy against acute mania [17-22]. There are only two small positive studies suggesting it might be effective in reducing the symptoms of depression and anxiety in bipolar I patients during the acute depressed episode $[23,24]$, (two more on the extended release form of valproate, one positive and one negative, have not been published $[25,26])$. One maintenance phase RCT was negative for valproate, however, it possibly suffered from a problematic study sample [27].

Carbamazepine is efficacious against acute mania [28-31], but with regard to acute bipolar depression there is only one dated positive small withdrawal study [28] and this is also the case for maintenance [32].

Lamotrigine is not effective against acute mania (two unpublished negative RCTs exist; SCAA2008 and SCAA2009) [16] and its efficacy in acute bipolar depression is controversial (five RCTs were negative on the primary outcome; SCA100223, SCA30924, SCA40910, SCAA2010 and SCAB2001 [33]; however, one of those was clearly positive on the Montgomery-Åsberg Depression Rating Scale (MADRS) [34] and the only adjunctive RCT was positive when lamotrigine was combined with lithium [35]. In contrast, there is strong evidence that during the maintenance phase, lamotrigine protects from depressive episodes but not from mania [36-40].

The data concerning the acute manic phase are negative for gabapentin [41] and topiramate [42].

There are some data concerning the efficacy of FGAs against acute mania but there are no data against bipolar depression or the maintenance phase. There is only one early, small, placebo-controlled study supporting the efficacy of chlorpromazine [43]. Several studies support the efficacy of haloperidol [44-48]. Most clinicians and experts believe that typical antipsychotics induce the opposite pole and cause dysphoria and depression. However, this has only been reported concerning haloperidol and perphenazine, suggesting that they could decrease the time to switch into depression compared with atypical antipsychotics $[49,50]$.

There are data supporting the efficacy of most SGAs against acute mania. However, data against acute bipolar depression and concerning maintenance are not homogenous.

Olanzapine has proven efficacy against acute mania [51-55]. Although there are also positive data concerning acute bipolar depression [56] there is concern on the effect on the 'depressive core' of symptoms although 
Table 1 Monotherapy data on the efficacy of agents and classes of agents in different phases of bipolar illness

\begin{tabular}{|c|c|c|c|c|}
\hline $\begin{array}{l}\text { Agent/modality (alphabetical } \\
\text { order) }\end{array}$ & Acute mania & $\begin{array}{l}\text { Acute bipolar } \\
\text { depression }\end{array}$ & $\begin{array}{l}\text { Maintenance against } \\
\text { mania }\end{array}$ & $\begin{array}{l}\text { Maintenance against } \\
\text { depression }\end{array}$ \\
\hline FGAs & Class effect & Unknown & Uncertain class effect & Unknown \\
\hline Chlorpromazine & Positive & - & - & - \\
\hline Haloperidol & Positive & - & - & - \\
\hline Perphenazine & - & - & Negative & - \\
\hline SGAs & Class effect & No class effect & Class effect & No class effect \\
\hline Amisulpride & - & - & - & - \\
\hline Aripiprazole & Positive & Negative & Positive & Negative \\
\hline Asenapine & Positive & - & - & - \\
\hline Clozapine & Positive & - & - & - \\
\hline Olanzapine & Positive & Equivocal & Positive & Positive \\
\hline Olanzapine-fluoxetine combination & - & Positive & - & - \\
\hline Paliperidone & Positive & - & - & - \\
\hline Quetiapine & Positive & Positive & Positive & Positive \\
\hline Risperidone & Positive & - & Positive & - \\
\hline Ziprasidone & Positive & - & Positive & - \\
\hline Antiepileptics & $\begin{array}{l}\text { No class } \\
\text { effect }\end{array}$ & No class effect & No class effect & No class effect \\
\hline Carbamazepine & Positive & Equivocal & Equivocal & Equivocal \\
\hline Gabapentin & Negative & - & - & - \\
\hline Lamotrigine & Negative & Negative & Negative & Positive \\
\hline Licarbazepine & Negative & - & - & - \\
\hline Topiramate & Negative & - & - & - \\
\hline Valproate & Positive & Equivocal & Equivocal & Equivocal \\
\hline Antidepressants & Unknown & No class effect & Unknown & No class effect \\
\hline Fluoxetine & - & Positive & - & Positive \\
\hline Paroxetine & - & Negative & - & - \\
\hline Venlafaxine & - & Equivocal & - & - \\
\hline
\end{tabular}

- = No data available.

it is certain that the patients manifested a significant improvement in symptoms 'peripheral' to the definition of depression such as insomnia, anxiety, loss of appetite and so on $[57,58]$. Maintenance data are positive concerning protection from manic, depressive and mixed episodes with olanzapine $[59,60]$ and with olanzapinefluoxetine combination (OFC) [56,61-64].

Quetiapine has proven efficacy against acute mania $[45,65,66]$, including an unpublished study (NCT00309699). The data are solid also against acute bipolar depression [67-74] and they are also effective against depression in bipolar II depression [75]. Combination data with a mood stabilizer and monotherapy are available concerning the maintenance phase $[76,77]$.

Aripiprazole is efficacious against acute mania [78-80] although one RCT with a fixed dosage design was negative [81]. Data are negative concerning bipolar depression [82]. During the maintenance phase it is reported to protect from manic relapses but not from depressive relapses [83,84]. Risperidone is efficacious against acute mania [46,85-87]. Recently, positive data concerning the maintenance phase became available for long-acting injectable risperidone, suggesting it is effective in the prevention of manic or mixed episodes but not depressive episodes [88]. Ziprasidone is efficacious against acute mania [48,89-91]. Data are negative concerning bipolar depression (two unpublished studies). There is one positive maintenance RCT with ziprasidone as an adjunct to valproate or lithium [92]. Asenapine is efficacious against acute mania $[54,93]$. No data are available concerning bipolar depression or the maintenance phase. The data are also positive for paliperidone against acute mania (one positive RCT with flexible dosage (NCT00309699) [94] and one negative with fixed dosage (NCT00299715)), but no data are available concerning bipolar depression or the maintenance phase.

The use and usefulness of antidepressants in bipolar disorder is controversial because of the risk of inducing 
the opposite pole. By definition, antidepressants are not used against acute mania (and there are no trials during the acute manic phase). From RCTs against acute bipolar depression, older studies suggested that amitriptiline [95] and maybe imipramine could be effective [96-98], with data being somewhat stronger for fluoxetine (particularly in bipolar II patients) [99-102]. As mentioned above, data are strong only for OFC [56,62-64]. At the same time, the data are negative for paroxetine monotherapy [103] and equivocal for venlafaxine, possibly because of a high switch rate [104]. A recent large, naturalistic study showed that up to $15 \%$ of the patients with mania receive antidepressants combined with antimanic agents, but this practice was actually associated with poorer outcomes compared to those who did not receive antidepressants [105].

Fluoxetine was reported to be effective during the maintenance phase for bipolar II patients $[100,101,106]$.

The data concerning combination and add-on treatment suggest that in acutely manic patients who are partial responders to lithium, valproate or carbamazepine, a good strategy would be to add haloperidol, risperidone, olanzapine, quetiapine or aripiprazole. Adding oxcarbazepine to lithium could also be a choice [107-124]. Combination data are negative for paliperidone (NCT00309686), positive for asenapine (NCT00145470 and NCT00145509) and negative for licarbazepine. Combination treatment studies in bipolar depression are equivocal [35,96-98,103,115,125-131]. A recent unpublished add-on study with ziprasidone (NCT00483548) was negative. Combination treatment during the maintenance phase includes quetiapine plus a mood stabilizer [76,77]; a discontinuation study on olanzapine as added on lithium or valproate was positive for olanzapine [132], and another discontinuation RCT of the combination of mood stabilizer plus ziprasidone was positive for ziprasidone [92]. Valproate was more effective than lithium when added on antidepressants for the prevention of bipolar depression [133].

A 40-week placebo controlled study of the safety and efficacy of asenapine when added to lithium or valproate (NCT00145509) and a 40-week extension study of asenapine vs olanzapine (Ares 7501007) have also been conducted.

Generally, add-on studies suggest that at least some strategies could be useful in patients with inadequate response to monotherapy. However the recently published BALANCE study could neither reliably confirm nor refute a benefit of combination therapy compared with lithium monotherapy [134] at least partially because of methodological flaws [135]. Overall, there is no compelling data that combination treatment does better than monotherapy. However, patients stabilized on combination treatment might do worse if shifted to monotherapy, and patients refractory to monotherapy could benefit with add-on treatment with olanzapine, aripiprazole, risperidone, quetiapine, ziprasidone, valproate, an antidepressant or lamotrigine, usually depending on the index acute phase.

A summary of the efficacy of various agents against the different phases of bipolar illness is shown in Table 1.

\section{Discussion}

In the current study, from the 16 'agent class'/' treatment issue' cases, only 3 possible class effects were detected. They all concern acute mania and antipsychotics (FGAs and SGAs against acute mania and SGAs in maintenance protecting from mania). Four effect cases are not adequately studied (FGAs against acute bipolar depression and in maintenance protecting from depression, antidepressants against acute mania and protecting from mania) and they all concern treatment cases with high risk of switching to the opposite pole; thus, research in these areas is poor.

What is impressive is the lack of any class effect concerning antiepileptics. This has been reported previously [136], and it is very interesting because anecdotal reports suggest that the average clinician considers the term 'antiepileptic' to be more or less interchangeable with 'mood stabilizer'. However, the data are only positive concerning valproate, carbamazepine and lamotrigine, and only against specific phases of the illness.

From a clinical point of view, depression and the maintenance phase seem to be more important since effective treatments are much fewer in comparison to acute mania. In particular, for the prevention of bipolar depressive episodes, the options seem to be quite limited, and no class effect is present.

Pharmacoepidemiological data are limited and usually concern established treatments such as lithium, valproate or antipsychotics, but they rarely concern nonestablished treatments such as newer antiepileptics. The lack of this kind of data is especially problematic for bipolar depression. An unpublished poster presentation from Japan reported that Japanese psychiatrists were divided between antidepressants and 'mood stabilizers' on the treatment of bipolar depression [137]. A study from the 1990s utilized the pharmacy records of McLean Hospital from 1987 to 1993 and reported that 3,829 bipolar depressive inpatients had received tricyclic antidepressants, 2,981 fluoxetine, 2,603 trazodone, 809 bupropion, 743 monoamine oxidase inhibitors, 592 stimulants, 588 sertraline, 48 paroxetine, and 894 electroconvulsive therapy [138]. Reports on real-world maintenance treatment suggest a variable picture. Baseline treatment data for the first 500 patients in the Systematic Treatment Enhancement Program for Bipolar 
Disorder (STEP-BD) study (1998 to 1999) revealed that while standard mood stabilizers (lithium, valproate, or carbamazepine) were the most commonly prescribed class of drugs for participants (71.9\%), the use of novel anticonvulsants was high (31.8\%) and more frequent than that of SGAs (27.2\%) [139]. Antidepressants are also prescribed as if there is a 'class effect' present during the maintenance phase. The US data from non-hospitalized subjects with bipolar I disorder in 1995/1996 suggested that more than half of all subjects were receiving concomitant antidepressants, of whom nearly $50 \%$ received selective serotonin reuptake inhibitor (SSRI) antidepressants and nearly $25 \%$ received buproprion [140]. The data from the 2002 to 2003 US national MarketScan research databases data suggest that the most commonly prescribed first drug class was antidepressants (50\% of patients) [141]. Baseline treatment data for the first 500 patients in the STEP-BD study (1998 to 1999) revealed that the second most common class of agents was antidepressants (40.6\%) [139]. In The Netherlands, the search of prescription patterns during 1996 to 2005 revealed a significant decrease in the use of tricyclic antidepressants, which, however, were still in wide use [142]. A Hungarian study reported that $35 \%$ of patients were on antidepressants and more than half of them on SSRIs, which implies a sustained wide use of tricyclics [143]. UK data from the case note review of patients from north-east England suggested that 23\% of patients were on antidepressants; $11 \%$ of them were not prescribed a mood stabilizer and $43 \%$ of antidepressants prescribed were tricyclics [144]. Taking the above together, it seems that depending on the sample, $25 \%$ to $50 \%$ of bipolar patients are cross-sectionally under antidepressants, with almost half of them receiving tricyclics.

It is true that the earlier studies tended to suggest a high and global effectiveness for older agents on all facets of bipolar disorder and a high prevalence of switching with antidepressants. Neither conclusion is confirmed by newer studies; however, since these conclusions were widely accepted for decades, these old agents are considered to be the 'gold standard' and 'class effects' were suggested to exist. The extent to which these 'class effects' truly influence everyday clinical practice worldwide is unknown; similarly the extent they influence the outcome of the treatment and the natural history of the disease is also unknown.

While evidence-based medicine has seemed to dominate medical scientific thinking in the last few decades, this is not true for wider clinical practice. The evidence is limited and hard to interpret and to carry over into everyday practice. However, it is highly likely that a significant number of patients worldwide are not receiving proper treatment simply because the 'class effect' idea discourages continued scientific training and reading. Focused educational intervention may be necessary to change this attitude.

\section{Conclusions}

In the treatment of bipolar disorder, a pharmaceutical class effect is the exception rather than the rule, and such class effects concern only acute mania and antipsychotics. Some facets of bipolar disorder have not been adequately studied to date; however, this does not seem to have influenced the general picture. Since a presumed 'class effect' is a very frequent and not adequately studied factor behind pharmaceutical prescription, the results of the current study suggest that a significant number of patients worldwide may not receive proper treatment. This situation can be corrected only by educational intervention, focused on changing this misconception.

\section{Author details \\ ${ }^{1}$ Third Department of Psychiatry, School of Medicine, Aristotle University of Thessaloniki, Greece. ${ }^{2}$ Department of Pharmacodynamics, Semmelweis University, Budapest, Hungary. ${ }^{3}$ Department of Clinical and Theoretical Mental Health, Faculty of Medicine, Semmelweis University, Budapest, Hungary. ${ }^{4}$ Bipolar Disorders Program, Hospital Clinic, IDIBAPS, CIBERSAM, University of Barcelona, Barcelona, Spain.}

\section{Authors' contributions}

KNF conducted the literature search, interpreted the results and wrote the first draft, and commented on following drafts. XG contributed to the interpretation of results, wrote subsequent drafts. EV contributed to the literature search and to the interpretation of results and commented on following drafts. ZR contributed to the interpretation of results and commented on following drafts.

\section{Competing interests}

KNF is/was member of the International Consultation Board of Wyeth for desvenlafaxine, BMS for aripiprazole in bipolar disorder and Servier for agomelatine and has received honoraria for lectures from AstraZeneca, Janssen-Cilag, Eli Lilly and research grants from AstraZeneca and Pfizer Foundation. XG has received travel support from GlaxoSmithKline, Krka, Lilly, Montrose, Organon, Richter, Sanofi, and Schering-Plough. EV has acted as consultant, received grants, or received honoraria for lectures by the following companies: Almirall, AstraZeneca, Bial, Bristol-Myers-Squibb, Eli Lilly, Forest Research Institute, GlaxoSmithKline, Janssen-Cilag, Jazz Lundbeck, Merck-Sharpe-Dohme, Novartis, Organon, Otsuka, Pfizer, Sanofi, Servier, Schering-Plough, Takeda, UBC, and Wyeth. ZR has received speaker's honoraria from AstraZeneca, GlaxoSmithKline, Lilly, Lundbeck, Organon, Pfizer, Richter, Sanofi-Aventis, Servier-EGIS, and Wyeth Pharmaceuticals. He also received honoraria as a member of scientific advisory boards of AstraZeneca, Lilly, Organon, Pfizer, Richer, Sanofi-Aventis and Servier-EGIS.

Received: 26 July 2010 Accepted: 24 March 2011

Published: 24 March 2011

\section{References}

1. Ng B, Camacho A, Lara DR, Brunstein MG, Pinto OC, Akiskal HS: A case series on the hypothesized connection between dementia and bipolar spectrum disorders: bipolar type VI? J Affect Disord 2008, 107:307-315.

2. Akiskal HS: The prevalent clinical spectrum of bipolar disorders: beyond DSM-IV. J Clin Psychopharmacol 1996, 16(Suppl 1):4S-14S.

3. Akiskal HS, Pinto O: The evolving bipolar spectrum. Prototypes I, II, III, and IV. Psychiatr Clin North Am 1999, 22:517-534, vii. 
4. Angst J: The emerging epidemiology of hypomania and bipolar II disorder. J Affect Disord 1998, 50:143-151.

5. Judd LL, Akiskal HS: The prevalence and disability of bipolar spectrum disorders in the US population: re-analysis of the ECA database taking into account subthreshold cases. J Affect Disord 2003, 73:123-131.

6. Acorn S: Mental and physical health of homeless persons who use emergency shelters in Vancouver. Hosp Community Psychiatry 1993, 44:854-857.

7. World Health Organization: The World Health Report 2003 - Shaping The Future Geneva, Switzerland: WHO; 2003.

8. Fountoulakis KN, Grunze H, Panagiotidis P, Kaprinis G: Treatment of bipolar depression: an update. J Affect Disord 2008, 109:21-34

9. Fountoulakis KN, Magiria S, Siamouli M, Panagiotidis P, Nimatoudis I, lacovides A, Kaprinis GS: A seven-year follow-up of an extremely refractory bipolar I patient. CNS Spectrum 2007, 12:733-734.

10. Fountoulakis KN, Vieta E, Sanchez-Moreno J, Kaprinis SG, Goikolea JM, Kaprinis GS: Treatment guidelines for bipolar disorder: a critical review. J Affect Disord 2005, 86:1-10.

11. Fountoulakis KN, Vieta E, Siamouli M, Valenti M, Magiria S, Oral T, Fresno D, Giannakopoulos P, Kaprinis GS: Treatment of bipolar disorder: a complex treatment for a multi-faceted disorder. Ann Gen Psychiatry 2007, 6:27.

12. Nivoli AM, Colom F, Murru A, Pacchiarotti I, Castro-Loli P, Gonzalez-Pinto A, Fountoulakis KN, Vieta E: New treatment guidelines for acute bipolar depression: a systematic review. J Affect Disord 2011, 129:14-26.

13. Fountoulakis KN: An update of evidence-based treatment of bipolar depression: where do we stand? Curr Opin Psychiatry 2010, 23:19-24.

14. Fountoulakis KN, Vieta E: Efficacy and safety of aripiprazole in the treatment of bipolar disorder: a systematic review. Ann Gen Psychiatry 2009, 8:16.

15. Fountoulakis KN, Gonda X, Vieta E, Schmidt F: Treatment of psychotic symptoms in bipolar disorder with aripiprazole monotherapy: a metaanalysis. Ann Gen Psychiatry 2009, 8:27.

16. Fountoulakis KN, Vieta E: Treatment of bipolar disorder: a systematic review of available data and clinical perspectives. Int $J$ Neuropsychopharmacol 2008, 11:999-1029.

17. Pope HG Jr, McElroy SL, Keck PE Jr, Hudson Jl: Valproate in the treatment of acute mania. A placebo-controlled study. Arch Gen Psychiatry 1991, 48:62-68.

18. Bowden $C L$, Brugger AM, Swann AC, Calabrese JR, Janicak PG, Petty F, Dilsaver SC, Davis JM, Rush AJ, Small JG, Garza-Treviño ES, Risch SC, Goodnick PJ, Morris DD, Depakote Mania Study Group, Shu V, Johnson P, Blake M, Javors M, Ereshefsky L, McLeod T, Shoaib A, Johnson M, Kimmel S, Wesley A, Qualtiere R, Trivedi C, Javaid J, Peterson J, Lambert M, et al: Efficacy of divalproex vs lithium and placebo in the treatment of mania. The Depakote Mania Study Group. JAMA 1994, 271:918-924.

19. Bowden CL, Swann AC, Calabrese JR, Rubenfaer LM, Wozniak PJ, Collins MA, Abi-Saab W, Saltarelli M: A randomized, placebo-controlled, multicenter study of divalproex sodium extended release in the treatment of acute mania. J Clin Psychiatry 2006, 67:1501-1510.

20. Tohen M, Vieta E, Goodwin GM, Sun B, Amsterdam JD, Banov M, Shekhar A, Aaronson ST, Bardenstein L, Grecu-Gabos I, Tochilov V, Prelipceanu D, Oliff HS, Kryzhanovskaya L, Bowden C: Olanzapine versus divalproex versus placebo in the treatment of mild to moderate mania: a randomized, 12-week, double-blind study. J Clin Psychiatry 2008, 69:1776-1789

21. Emrich HM, von Zerssen D, Kissling W, Moller HJ, Windorfer A: Effect of sodium valproate on mania. The GABA-hypothesis of affective disorders. Archiv fur Psychiatrie und Nervenkrankheiten 1980, 229:1-16.

22. Emrich HM, von Zerssen D, Kissling W, Moller HJ: Therapeutic effect of valproate in mania. Am J Psychiatry 1981, 138:256.

23. Davis LL, Bartolucci A, Petty F: Divalproex in the treatment of bipolar depression: a placebo-controlled study. J Affect Disord 2005, 85:259-266.

24. Ghaemi SN, Gilmer WS, Goldberg JF, Zablotsky B, Kemp DE, Kelley ME, Bauer AD, Fleck J, Filkowski MM, Stan VA, Dunn RT: Divalproex in the treatment of acute bipolar depression: a preliminary double-blind, randomized, placebo-controlled pilot study. J Clin Psychiatry 2007, 68:1840-1844.

25. Bond DJ, Lam RW, Yatham LN: Divalproex sodium versus placebo in the treatment of acute bipolar depression: a systematic review and metaanalysis. J Affect Disord 2010, 124:228-234
26. Smith LA, Cornelius VR, Azorin JM, Perugi G, Vieta E, Young AH, Bowden CL: Valproate for the treatment of acute bipolar depression: Systematic review and meta-analysis. $J$ Affect Disord 2010, 122:1-9.

27. Bowden CL, Calabrese JR, McElroy SL, Gyulai L, Wassef A, Petty F, Pope HG Jr, Chou JC, Keck PE Jr, Rhodes LJ, Swann AC, Hirschfeld RM, Wozniak PJ: A randomized, placebo-controlled 12-month trial of divalproex and lithium in treatment of outpatients with bipolar I disorder. Divalproex Maintenance Study Group. Arch Gen Psychiatry 2000, 57:481-489.

28. Ballenger JC, Post RM: Carbamazepine in manic-depressive illness: a new treatment. Am J Psychiatry 1980, 137:782-790.

29. Weisler RH, Kalali AH, Ketter TA: A multicenter, randomized, double-blind, placebo-controlled trial of extended-release carbamazepine capsules as monotherapy for bipolar disorder patients with manic or mixed episodes. J Clin Psychiatry 2004, 65:478-484.

30. Weisler RH, Hirschfeld R, Cutler AJ, Gazda T, Ketter TA, Keck PE, Swann A, Kalali A: Extended-release carbamazepine capsules as monotherapy in bipolar disorder: pooled results from two randomised, double-blind, placebo-controlled trials. CNS Drugs 2006, 20:219-231.

31. Weisler RH, Keck PE Jr, Swann AC, Cutler AJ, Ketter TA, Kalali AH: Extendedrelease carbamazepine capsules as monotherapy for acute mania in bipolar disorder: a multicenter, randomized, double-blind, placebocontrolled trial. J Clin Psychiatry 2005, 66:323-330.

32. Okuma T, Inanaga K, Otsuki S, Sarai K, Takahashi R, Hazama H, Mori A, Watanabe S: A preliminary double-blind study on the efficacy of carbamazepine in prophylaxis of manic-depressive illness. Psychopharmacology (Berl) 1981, 73:95-96.

33. Goldsmith DR, Wagstaff AJ, Ibbotson T, Perry CM: Lamotrigine: a review of its use in bipolar disorder. Drugs 2003, 63:2029-2050.

34. Calabrese JR, Bowden CL, Sachs GS, Ascher JA, Monaghan E, Rudd GD: A double-blind placebo-controlled study of lamotrigine monotherapy in outpatients with bipolar I depression. Lamictal 602 Study Group. J Clin Psychiatry 1999, 60:79-88.

35. van der Loos ML, Mulder PG, Hartong EG, Blom MB, Vergouwen AC, de Keyzer HJ, Notten PJ, Luteijn ML, Timmermans MA, Vieta E, Nolen WA LamLit Study Group: Efficacy and safety of lamotrigine as add-on treatment to lithium in bipolar depression: a multicenter, double-blind, placebo-controlled trial. J Clin Psychiatry 2009, 70:223-231.

36. Bowden CL, Calabrese JR, Sachs G, Yatham LN, Asghar SA, Hompland M Montgomery P, Earl N, Smoot TM, DeVeaugh-Geiss J: A placebo-controlled 18-month trial of lamotrigine and lithium maintenance treatment in recently manic or hypomanic patients with bipolar I disorder. Arch Gen Psychiatry 2003, 60:392-400.

37. Calabrese JR, Bowden CL, Sachs G, Yatham LN, Behnke K, Mehtonen OP, Montgomery P, Ascher J, Paska W, Earl N, DeVeaugh-Geiss J, Lamictal 605 Study Group: A placebo-controlled 18-month trial of lamotrigine and lithium maintenance treatment in recently depressed patients with bipolar I disorder. J Clin Psychiatry 2003, 64:1013-1024.

38. Calabrese JR, Goldberg JF, Ketter TA, Suppes T, Frye M, White R, DeVeaughGeiss A, Thompson TR: Recurrence in bipolar I disorder: a post hoc analysis excluding relapses in two double-blind maintenance studies. Biol Psychiatry 2006, 59:1061-1064.

39. Calabrese JR, Vieta E, Shelton MD: Latest maintenance data on lamotrigine in bipolar disorder. Eur Neuropsychopharmacol 2003, 13(Suppl 2):S57-66.

40. Goodwin GM, Bowden CL, Calabrese JR, Grunze H, Kasper S, White R, Greene P, Leadbetter R: A pooled analysis of 2 placebo-controlled 18month trials of lamotrigine and lithium maintenance in bipolar I disorder. J Clin Psychiatry 2004, 65:432-441.

41. Frye MA, Ketter TA, Kimbrell TA, Dunn RT, Speer AM, Osuch EA, Luckenbaugh DA, Cora-Ocatelli G, Leverich GS, Post RM: A placebocontrolled study of lamotrigine and gabapentin monotherapy in refractory mood disorders. J Clin Psychopharmacol 2000, 20:607-614.

42. Kushner SF, Khan A, Lane R, Olson WH: Topiramate monotherapy in the management of acute mania: results of four double-blind placebocontrolled trials. Bipolar Disord 2006, 8:15-27.

43. Klein DF: Importance of psychiatric diagnosis in prediction of clinical drug effects. Arch Gen Psychiatry 1967, 16:118-126.

44. Shopsin B, Gershon S, Thompson H, Collins P: Psychoactive drugs in mania. A controlled comparison of lithium carbonate, chlorpromazine, and haloperidol. Arch Gen Psychiatry 1975, 32:34-42. 
45. Mclntyre RS, Brecher M, Paulsson B, Huizar K, Mullen J: Quetiapine or haloperidol as monotherapy for bipolar mania - a 12-week, doubleblind, randomised, parallel-group, placebo-controlled trial. Eur Neuropsychopharmacol 2005, 15:573-585.

46. Smulevich AB, Khanna S, Eerdekens M, Karcher K, Kramer M, Grossman F: Acute and continuation risperidone monotherapy in bipolar mania: a 3week placebo-controlled trial followed by a 9-week double-blind trial of risperidone and haloperidol. Eur Neuropsychopharmacol 2005, 15:75-84.

47. Young A, Oren D, Lowy A, McQuade RD, Marcus RN, Carson W, Spiller N, Torbeyns A, Sanchez R: Aripiprazol monotherapy in acute mania: a 12week, randomized, placebo and haloperidol- controlled study. $\mathrm{Br} J$ Psychiatry 2009, 194:40-48.

48. Vieta E, Ramey T, Keller D, English P, Loebel A, Miceli J: Ziprasidone in the treatment of acute mania: a 12-week, placebo-controlled, haloperidolreferenced study. J Psychopharmacol 2010, 4:547-558.

49. Tohen M, Goldberg JF, Gonzalez-Pinto Arrillaga AM, Azorin JM, Vieta E, Hardy-Bayle MC, Lawson WB, Emsley RA, Zhang F, Baker RW, Risser RC, Namjoshi MA, Evans AR, Breier A: A 12-week, double-blind comparison of olanzapine vs haloperidol in the treatment of acute mania. Arch Gen Psychiatry 2003, 60:1218-1226.

50. Zarate CA Jr, Tohen M: Double-blind comparison of the continued use of antipsychotic treatment versus its discontinuation in remitted manic patients. Am J Psychiatry 2004, 161:169-171.

51. Tohen M, Sanger TM, McElroy SL, Tollefson GD, Chengappa KN, Daniel DG, Petty F, Centorrino F, Wang R, Grundy SL, Greaney MG, Jacobs TG, David SR, Toma V: Olanzapine versus placebo in the treatment of acute mania. Olanzapine HGEH Study Group. Am J Psychiatry 1999, 156:702-709.

52. Tohen M, Jacobs TG, Grundy SL, McElroy SL, Banov MC, Janicak PG, Sanger T, Risser R, Zhang F, Toma V, Francis J, Tollefson GD, Breier A: Efficacy of olanzapine in acute bipolar mania: a double-blind, placebocontrolled study. The Olanzipine HGGW Study Group. Arch Gen Psychiatry 2000, 57:841-849.

53. Mclntyre RS, Cohen M, Zhao J, Alphs L, Macek TA, Panagides J: Asenapine in the treatment of acute mania in bipolar I disorder: A randomized, double-blind, placebo-controlled trial. J Affect Disord 2010, 122:27-38.

54. McIntyre RS, Cohen M, Zhao J, Alphs L, Macek TA, Panagides J: A 3-week, randomized, placebo-controlled trial of asenapine in the treatment of acute mania in bipolar mania and mixed states. Bipolar Disord 2009, 11:673-686.

55. Meehan K, Zhang F, David S, Tohen M, Janicak P, Small J, Koch M, Rizk R, Walker D, Tran P, Breier A: A double-blind, randomized comparison of the efficacy and safety of intramuscular injections of olanzapine, lorazepam, or placebo in treating acutely agitated patients diagnosed with bipolar mania. J Clin Psychopharmacol 2001, 21:389-397.

56. Tohen M, Vieta E, Calabrese J, Ketter TA, Sachs G, Bowden C, Mitchell PB, Centorrino F, Risser R, Baker RW, Evans AR, Beymer K, Dube S, Tollefson GD, Breier A: Efficacy of olanzapine and olanzapine-fluoxetine combination in the treatment of bipolar I depression. Arch Gen Psychiatry 2003, 60:1079-1088.

57. Bech P: Meta-analysis of placebo-controlled trials with mirtazapine using the core items of the Hamilton Depression Scale as evidence of a pure antidepressive effect in the short-term treatment of major depression. Int J Neuropsychopharmacol 2001, 4:337-345.

58. Lecrubier $Y$, Bech $P$ : The Ham $\mathrm{D}(6)$ is more homogenous and as sensitive as the Ham D(17). Eur Psychiatry 2007, 22:252-255.

59. Tohen M, Calabrese JR, Sachs GS, Banov MD, Detke HC, Risser R, Baker RW, Chou JC, Bowden CL: Randomized, placebo-controlled trial of olanzapine as maintenance therapy in patients with bipolar I disorder responding to acute treatment with olanzapine. Am J Psychiatry 2006, 163:247-256.

60. Tohen M, Sutton VK, Calabrese JR, Sachs GS, Bowden CL: Maintenance of response following stabilization of mixed index episodes with olanzapine monotherapy in a randomized, double-blind, placebocontrolled study of bipolar 1 disorder. J Affect Disord 2009, 116:43-50.

61. Brown E, Dunner DL, McElroy SL, Keck PE, Adams DH, Degenhardt E, Tohen M, Houston JP: Olanzapine/fluoxetine combination vs. lamotrigine in the 6-month treatment of bipolar I depression. Int J Neuropsychopharmacol 2009, 12:773-782.

62. Brown EB, McElroy SL, Keck PE Jr, Deldar A, Adams DH, Tohen M, Williamson DJ: A 7-week, randomized, double-blind trial of olanzapine/ fluoxetine combination versus lamotrigine in the treatment of bipolar I depression. J Clin Psychiatry 2006, 67:1025-1033.

63. Shi L, Namjoshi MA, Swindle R, Yu X, Risser R, Baker RW, Tohen M: Effects of olanzapine alone and olanzapine/fluoxetine combination on healthrelated quality of life in patients with bipolar depression: secondary analyses of a double-blind, placebo-controlled, randomized clinical trial. Clin Ther 2004, 26:125-134.

64. Dube S, Tollefson GD, Thase ME, Briggs SD, Van Campen LE, Case M, Tohen M: Onset of antidepressant effect of olanzapine and olanzapine/ fluoxetine combination in bipolar depression. Bipolar Disord 2007, 9:618-627.

65. Bowden $\mathrm{CL}$, Grunze H, Mullen J, Brecher M, Paulsson B, Jones M, Vagero M, Svensson K: A randomized, double-blind, placebo-controlled efficacy and safety study of quetiapine or lithium as monotherapy for mania in bipolar disorder. J Clin Psychiatry 2005, 66:111-121.

66. McElroy SL, Martens BE, Winstanley EL, Creech R, Malhotra S, Keck PE Jr: Placebo-controlled study of quetiapine monotherapy in ambulatory bipolar spectrum disorder with moderate-to-severe hypomania or mild mania. J Affect Disord 2010, 124:157-163.

67. Calabrese JR, Keck PE Jr, Macfadden W, Minkwitz M, Ketter TA, Weisler RH, Cutler AJ, McCoy R, Wilson E, Mullen J: A randomized, double-blind, placebo-controlled trial of quetiapine in the treatment of bipolar I or II depression. Am J Psychiatry 2005, 162:1351-1360.

68. McElroy SL, Weisler RH, Chang W, Olausson B, Paulsson B, Brecher M, Agambaram V, Merideth C, Nordenhem A, Young AH: A double-blind, placebo-controlled study of quetiapine and paroxetine as monotherapy in adults with bipolar depression (EMBOLDEN II). J Clin Psychiatry 2010, 71:163-174.

69. Young AH, McElroy SL, Bauer M, Philips N, Chang W, Olausson B, Paulsson B, Brecher M: A double-blind, placebo-controlled study of quetiapine and lithium monotherapy in adults in the acute phase of bipolar depression (EMBOLDEN I). J Clin Psychiatry 2010, 71:150-162.

70. Thase ME, Macfadden W, Weisler RH, Chang W, Paulsson B, Khan A, Calabrese JR: Efficacy of quetiapine monotherapy in bipolar I and II depression: a double-blind, placebo-controlled study (the BOLDER II study). J Clin Psychopharmacol 2006, 26:600-609.

71. Suppes T, Datto C, Minkwitz M, Nordenhem A, Walker C, Darko D: Effectiveness of the extended release formulation of quetiapine as monotherapy for the treatment of acute bipolar depression. J Affect Disord 2010, 121:106-115.

72. Cookson J, Keck PE Jr, Ketter TA, Macfadden W: Number needed to treat and time to response/remission for quetiapine monotherapy efficacy in acute bipolar depression: evidence from a large, randomized, placebocontrolled study. Int Clin Psychopharmacol 2007, 22:93-100.

73. Weisler RH, Calabrese JR, Thase ME, Arvekvist R, Stening G, Paulsson B, Suppes T: Efficacy of quetiapine monotherapy for the treatment of depressive episodes in bipolar I disorder: a post hoc analysis of combined results from 2 double-blind, randomized, placebo-controlled studies. J Clin Psychiatry 2008, 69:769-782.

74. Endicott J, Rajagopalan K, Minkwitz M, Macfadden W: A randomized, double-blind, placebo-controlled study of quetiapine in the treatment of bipolar I and II depression: improvements in quality of life. Int Clin Psychopharmacol 2007, 22:29-37.

75. Suppes T, Hirschfeld RM, Vieta E, Raines S, Paulsson B: Quetiapine for the treatment of bipolar II depression: analysis of data from two randomized, double-blind, placebo-controlled studies. World J Biol Psychiatry 2008, 9:198-211.

76. Vieta E, Suppes T, Eggens I, Persson I, Paulsson B, Brecher M: Efficacy and safety of quetiapine in combination with lithium or divalproex for maintenance of patients with bipolar I disorder (international trial 126). J Affect Disord 2008, 109:251-263.

77. Suppes T, Vieta E, Liu S, Brecher M, Paulsson B: Maintenance treatment for patients with bipolar I disorder: results from a north american study of quetiapine in combination with lithium or divalproex (trial 127). Am J Psychiatry 2009, 166:476-488.

78. Keck PE Jr, Marcus R, Tourkodimitris S, Ali M, Liebeskind A, Saha A, Ingenito G: A placebo-controlled, double-blind study of the efficacy and safety of aripiprazole in patients with acute bipolar mania. Am J Psychiatry 2003, 160:1651-1658.

79. Sachs G, Sanchez R, Marcus R, Stock E, McQuade R, Carson W, AbouGharbia N, Impellizzeri C, Kaplita S, Rollin L, Iwamoto T, Aripiprazole Study 
Group: Aripiprazole in the treatment of acute manic or mixed episodes in patients with bipolar I disorder: a 3-week placebo-controlled study. Psychopharmacol 2006, 20:536-546.

80. Keck PE, Orsulak PJ, Cutler AJ, Sanchez R, Torbeyns A, Marcus RN, McQuade RD, Carson WH, (CN138-135 Study Group): Aripiprazole monotherapy in the treatment of acute bipolar I mania: a randomized, double-blind, placebo- and lithium-controlled study. J Affect Disord 2009, 112:36-49.

81. Garcia-Amador M, Pacchiarotti I, Valenti M, Sanchez RF, Goikolea JM, Vieta E: Role of aripiprazole in treating mood disorders. Exp Rev Neurotherapeutics 2006, 6:1777-1783.

82. Thase ME, Jonas A, Khan A, Bowden CL, Wu X, McQuade RD, Carson WH, Marcus RN, Owen R: Aripiprazole monotherapy in nonpsychotic bipolar I depression: results of 2 randomized, placebo-controlled studies. J Clin Psychopharmacol 2008, 28:13-20.

83. Keck PE Jr, Calabrese JR, McQuade RD, Carson WH, Carlson BX, Rollin LM, Marcus RN, Sanchez R: A randomized, double-blind, placebo-controlled 26-week trial of aripiprazole in recently manic patients with bipolar I disorder. J Clin Psychiatry 2006, 67:626-637.

84. Keck PE Jr, Calabrese JR, McIntyre RS, McQuade RD, Carson WH, Eudicone JM, Carlson BX, Marcus RN, Sanchez R: Aripiprazole monotherapy for maintenance therapy in bipolar I disorder: a 100-week, double-blind study versus placebo. J Clin Psychiatry 2007, 68:1480-1491.

85. Gopal S, Steffens DC, Kramer ML, Olsen MK: Symptomatic remission in patients with bipolar mania: results from a double-blind, placebocontrolled trial of risperidone monotherapy. J Clin Psychiatry 2005, 66:1016-1020.

86. Hirschfeld RM, Keck PE Jr, Kramer M, Karcher K, Canuso C, Eerdekens M, Grossman F: Rapid antimanic effect of risperidone monotherapy: a 3week multicenter, double-blind, placebo-controlled trial. Am J Psychiatry 2004, 161:1057-1065.

87. Khanna S, Vieta E, Lyons B, Grossman F, Eerdekens M, Kramer M: Risperidone in the treatment of acute mania: double-blind, placebocontrolled study. Br J Psychiatry 2005, 187:229-234.

88. Quiroz JA, Yatham LN, Palumbo JM, Karcher K, Kushner S, Kusumakar V: Risperidone long-acting injectable monotherapy in the maintenance treatment of bipolar I disorder. Biol Psychiatry 2010, 68:156-162.

89. Keck PE Jr, Versiani M, Potkin S, West SA, Giller E, Ice K: Ziprasidone in the treatment of acute bipolar mania: a three-week, placebo-controlled, double-blind, randomized trial. Am J Psychiatry 2003, 160:741-748.

90. Potkin SG, Keck PE Jr, Segal S, Ice K, English P: Ziprasidone in acute bipolar mania: a 21-day randomized, double-blind, placebo-controlled replication trial. J Clin Psychopharmacol 2005, 25:301-310.

91. Stahl S, Lombardo I, Loebel A, Mandel FS: Efficacy of ziprasidone in dysphoric mania: pooled analysis of two double-blind studies. J Affect Disord 2010, 122:39-45.

92. Bowden CL, Vieta E, Ice KS, Schwartz JH, Wang PP, Versavel M: Ziprasidone plus a mood stabilizer in subjects with bipolar I disorder: a 6-month, randomized, placebo-controlled, double-blind trial. J Clin Psychiatry 2010, 71:130-137.

93. Mclntyre RS, Cohen M, Zhao J, Alphs L, Macek TA, Panagides J: Asenapine in the treatment of acute mania in bipolar I disorder: a randomized, double-blind, placebo-controlled trial. J Affect Disord 2010, 122:27-38.

94. Vieta E, Nuamah IF, Lim P, Yuen EC, Palumbo JM, Hough DW, Berwaerts J: A randomized, placebo- and active-controlled study of paliperidone extended release for the treatment of acute manic and mixed episodes of bipolar I disorder. Bipolar Disord 2010, 12:230-243.

95. Glen Al, Johnson AL, Shepherd M: Continuation therapy with lithium and amitriptyline in unipolar depressive illness: a randomized, double-blind, controlled trial. Psychol Med 1984, 14:37-50.

96. Prien RF, Kupfer DJ, Mansky PA, Small JG, Tuason VB, Voss CB, Johnson WE: Drug therapy in the prevention of recurrences in unipolar and bipolar affective disorders. Report of the NIMH Collaborative Study Group comparing lithium carbonate, imipramine, and a lithium carbonateimipramine combination. Arch Gen Psychiatry 1984, 41:1096-1104.

97. Prien RF, Klett CJ, Caffey EM Jr: Lithium carbonate and imipramine in prevention of affective episodes. A comparison in recurrent affective illness. Arch Gen Psychiatry 1973, 29:420-425.

98. Kane JM, Quitkin FM, Rifkin A, Ramos-Lorenzi JR, Nayak DD, Howard A: Lithium carbonate and imipramine in the prophylaxis of unipolar and bipolar II illness: a prospective, placebo-controlled comparison. Arch Gen Psychiatry 1982, 39:1065-1069.

99. Cohn JB, Collins G, Ashbrook E, Wernicke JF: A comparison of fluoxetine imipramine and placebo in patients with bipolar depressive disorder. Int Clin Psychopharmacol 1989, 4:313-322.

100. Amsterdam JD, Garcia-Espana F, Fawcett J, Quitkin FM, Reimherr FW, Rosenbaum JF, Schweizer E, Beasley C: Efficacy and safety of fluoxetine in treating bipolar II major depressive episode. J Clin Psychopharmacol 1998, 18:435-440.

101. Amsterdam JD, Shults J: Comparison of fluoxetine, olanzapine, and combined fluoxetine plus olanzapine initial therapy of bipolar type I and type II major depression-lack of manic induction. J Affect Disord 2005, 87:121-130.

102. Parker G, Tully L, Olley A, Hadzi-Pavlovic D: SSRIs as mood stabilizers for bipolar II disorder? A proof of concept study. J Affect Disord 2006, 92:205-214.

103. McElroy SL, Weisler RH, Chang W, Olausson B, Paulsson B, Brecher M, Agambaram V, Merideth C, Nordenhem A, Young AH: A double-blind, placebo-controlled study of quetiapine and paroxetine as monotherapy in adults with bipolar depression (EMBOLDEN II). J Clin Psychiatry 2010, 71:163-174.

104. Vieta E, Martinez-Aran A, Goikolea JM, Torrent C, Colom F, Benabarre A, Reinares $\mathrm{M}$ : A randomized trial comparing paroxetine and venlafaxine in the treatment of bipolar depressed patients taking mood stabilizers. J Clin Psychiatry 2002, 63:508-512.

105. Rosa AR, Cruz N, Franco C, Haro JM, Bertsch J, Reed C, Aarre TF, SanchezMoreno J, Vieta E: Why do clinicians maintain antidepressants in some patients with acute mania? Hints from the European Mania in Bipolar Longitudinal Evaluation of Medication (EMBLEM), a large naturalistic study. J Clin Psychiatry 2010, 71:1000-1006.

106. Amsterdam JD, Shults J: Fluoxetine monotherapy of bipolar type II and bipolar NOS major depression: a double-blind, placebo-substitution, continuation study. Int Clin Psychopharmacol 2005, 20:257-264.

107. Garfinkel PE, Stancer HC, Persad E: A comparison of haloperidol, lithium carbonate and their combination in the treatment of mania. J Affect Disord 1980, 2:279-288.

108. Sachs GS, Grossman F, Ghaemi SN, Okamoto A, Bowden CL: Combination of a mood stabilizer with risperidone or haloperidol for treatment of acute mania: a double-blind, placebo-controlled comparison of efficacy and safety. Am J Psychiatry 2002, 159:1146-1154.

109. Chou JC, Czobor P, Charles O, Tuma I, Winsberg B, Allen MH, Trujillo M, Volavka J: Acute mania: haloperidol dose and augmentation with lithium or lorazepam. J Clin Psychopharmacol 1999, 19:500-505.

110. Lenox RH, Newhouse PA, Creelman WL, Whitaker TM: Adjunctive treatment of manic agitation with lorazepam versus haloperidol: a double-blind study. J Clin Psychiatry 1992, 53:47-52.

111. Small JG, Klapper MH, Marhenke JD, Milstein V, Woodham GC, Kellams JJ: Lithium combined with carbamazepine or haloperidol in the treatment of mania. Psychopharmacol Bull 1995, 31:265-272.

112. Klein E, Bental E, Lerer B, Belmaker RH: Carbamazepine and haloperidol v placebo and haloperidol in excited psychoses. A controlled study. Arch Gen Psychiatry 1984, 41:165-170.

113. Tohen M, Bowden $C L$, Smulevich AB, Bergstrom R, Quinlan T, Osuntokun O, Wang WV, Oliff HS, Martenyi F, Kryzhanovskaya LA, Greil W: Olanzapine plus carbamazepine v. carbamazepine alone in treating manic episodes. Br J Psychiatry 2008, 192:135-143.

114. Yatham LN, Grossman F, Augustyns I, Vieta E, Ravindran A: Mood stabilisers plus risperidone or placebo in the treatment of acute mania. International, double-blind, randomised controlled trial. Br J Psychiatry 2003, 182:141-147

115. Juruena MF, Ottoni GL, Machado-Vieira R, Carneiro RM, Weingarthner N, Marquardt AR, Fleig SS, Broilo L, Busnello EA: Bipolar I and II disorder residual symptoms: oxcarbazepine and carbamazepine as add-on treatment to lithium in a double-blind, randomized trial. Prog Neuropsychopharmacol Biol Psychiatry 2009, 33:94-99.

116. T Tohen M, Chengappa KN, Suppes T, Zarate CA Jr, Calabrese JR, Bowden CL, Sachs GS, Kupfer DJ, Baker RW, Risser RC, Keeter EL, Feldman PD, Tollefson GD, Breier A: Efficacy of olanzapine in combination with valproate or lithium in the treatment of mania in patients partially nonresponsive to valproate or lithium monotherapy. Arch Gen Psychiatry 2002, 59:62-69. 
117. Houston JP, Ahl J, Meyers AL, Kaiser CJ, Tohen M, Baldessarini RJ: Reduced suicidal ideation in bipolar I disorder mixed-episode patients in a placebo-controlled trial of olanzapine combined with lithium or divalproex. J Clin Psychiatry 2006, 67:1246-1252.

118. Sachs G, Chengappa KN, Suppes T, Mullen JA, Brecher M, Devine NA, Sweitzer DE: Quetiapine with lithium or divalproex for the treatment of bipolar mania: a randomized, double-blind, placebo-controlled study. Bipolar Disord 2004, 6:213-223.

119. Yatham LN, Paulsson B, Mullen J, Vagero AM: Quetiapine versus placebo in combination with lithium or divalproex for the treatment of bipolar mania. J Clin Psychopharmacol 2004, 24:599-606.

120. Yatham LN, Vieta E, Young AH, Moller HJ, Paulsson B, Vagero M: A double blind, randomized, placebo-controlled trial of quetiapine as an add-on therapy to lithium or divalproex for the treatment of bipolar mania. Int Clin Psychopharmacol 2007, 22:212-220.

121. Vieta E, T'Joen C, McQuade RD, Carson WH Jr, Marcus RN, Sanchez R, Owen R, Nameche L: Efficacy of adjunctive aripiprazole to either valproate or lithium in bipolar mania patients partially nonresponsive to valproate/lithium monotherapy: a placebo-controlled study. Am J Psychiatry 2008, 165:1316-1325

122. Muller-Oerlinghausen B, Retzow A, Henn FA, Giedke H, Walden J: Valproate as an adjunct to neuroleptic medication for the treatment of acute episodes of mania: a prospective, randomized, double-blind, placebocontrolled, multicenter study. European Valproate Mania Study Group. J Clin Psychopharmacol 2000, 20:195-203.

123. Weisler R, Dunn J, English P: Adjunctive Ziprasidone for acute bipolar mania: randomized, placebo-controlled trial. 4th International Forum on Mood and Anxiety Disorders Monte Carlo, Monaco; 2003.

124. Roy Chengappa KN, Schwarzman LK, Hulihan JF, Xiang J, Rosenthal NR: Adjunctive topiramate therapy in patients receiving a mood stabilizer for bipolar I disorder: a randomized, placebo-controlled trial. J Clin Psychiatry 2006, 67:1698-1706

125. Nemeroff CB, Evans DL, Gyulai L, Sachs GS, Bowden CL, Gergel IP, Oakes R, Pitts CD: Double-blind, placebo-controlled comparison of imipramine and paroxetine in the treatment of bipolar depression. Am J Psychiatry 2001, 158:906-912.

126. Post RM, Altshuler LL, Frye MA, Suppes T, Rush AJ, Keck PE Jr, McElroy SL, Denicoff KD, Leverich GS, Kupka R, Nolen WA: Rate of switch in bipolar patients prospectively treated with second-generation antidepressants as augmentation to mood stabilizers. Bipolar Disord 2001, 3:259-265.

127. Post RM, Altshuler LL, Leverich GS, Frye MA, Nolen WA, Kupka RW, Suppes T, McElroy S, Keck PE, Denicoff KD, Grunze H, Walden J, Kitchen CM, Mintz J: Mood switch in bipolar depression: comparison of adjunctive venlafaxine, bupropion and sertraline. Br J Psychiatry 2006, 189:124-131.

128. Altshuler LL, Post RM, Hellemann G, Leverich GS, Nolen WA, Frye MA, Keck PE Jr, Kupka RW, Grunze H, McElroy SL, Sugar CA, Suppes T: Impact of antidepressant continuation after acute positive or partial treatment response for bipolar depression: a blinded, randomized study. J Clin Psychiatry 2009, 70:450-457.

129. Schaffer A, Zuker P, Levitt A: Randomized, double-blind pilot trial comparing lamotrigine versus citalopram for the treatment of bipolar depression. J Affect Disord 2006, 96:95-99.

130. Sachs GS, Nierenberg AA, Calabrese JR, Marangell LB, Wisniewski SR, Gyulai L, Friedman ES, Bowden CL, Fossey MD, Ostacher MJ, Ketter TA, Patel J, Hauser P, Rapport D, Martinez JM, Allen MH, Miklowitz DJ, Otto MW, Dennehy EB, Thase ME: Effectiveness of adjunctive antidepressant treatment for bipolar depression. N Engl J Med 2007, 356:1711-1722.

131. Young LT, Joffe RT, Robb JC, MacQueen GM, Marriott M, Patelis-Siotis I: Double-blind comparison of addition of a second mood stabilizer versus an antidepressant to an initial mood stabilizer for treatment of patients with bipolar depression. Am J Psychiatry 2000, 157:124-126.

132. Tohen M, Chengappa KN, Suppes T, Baker RW, Zarate CA, Bowden CL, Sachs GS, Kupfer DJ, Ghaemi SN, Feldman PD, Risser RC, Evans AR, Calabrese JR: Relapse prevention in bipolar I disorder: 18-month comparison of olanzapine plus mood stabiliser v. mood stabiliser alone. Br J Psychiatry 2004, 184:337-345.

133. Gyulai L, Bowden CL, McElroy SL, Calabrese JR, Petty F, Swann AC, Chou JC, Wassef A, Risch CS, Hirschfeld RM, Nemeroff CB, Keck PE Jr, Evans DL, Wozniak PJ: Maintenance efficacy of divalproex in the prevention of bipolar depression. Neuropsychopharmacology 2003, 28:1374-1382.
134. Geddes JR, Goodwin GM, Rendell J, Azorin JM, Cipriani A, Ostacher MJ, Morriss R, Alder N, Juszczak E: Lithium plus valproate combination therapy versus monotherapy for relapse prevention in bipolar I disorder (BALANCE): a randomised open-label trial. Lancet 2010, 375:385-395.

135. Fountoulakis KN: The BALANCE trial. Lancet 375:1343-1344.

136. Rosa AR, Fountoulakis K, Siamouli M, Gonda X, Vieta E: Is anticonvulsant treatment of mania a class effect? Data from randomized clinical trials. CNS Neurosci Ther 2009.

137. Oshima A, Higuchi T, Fujiwara $Y$, lida M, Iwanami A, Kanba S, Motohashi N, Uchitomi Y, Yamada K, Yamawaki S: Questionnaire survey on the prescribing practice of Japanese psychiatrists for mood disorders. Psychiatry Clin Neurosci 1999, 53(Suppl):S67-72.

138. Zarate CA Jr, Tohen M, Baraibar G, Kando JC, Mirin J: Prescribing trends of antidepressants in bipolar depression. J Clin Psychiatry 1995, 56:260-264.

139. Ghaemi SN, Hsu DJ, Thase ME, Wisniewski SR, Nierenberg AA, Miyahara S, Sachs G: Pharmacological treatment patterns at study entry for the first 500 STEP-BD participants. Psychiatric Serv 2006, 57:660-665.

140. Levine J, Chengappa KN, Brar JS, Gershon S, Yablonsky E, Stapf D, Kupfer DJ: Psychotropic drug prescription patterns among patients with bipolar I disorder. Bipolar Disord 2000, 2:120-130.

141. Baldessarini RJ, Leahy L, Arcona S, Gause D, Zhang W, Hennen J: Patterns of psychotropic drug prescription for U.S. patients with diagnoses of bipolar disorders. Psychiatric Serv 2007, 58:85-91.

142. Wilting I, Souverein PC, Nolen WA, Egberts AC, Heerdink ER: Changes in outpatient lithium treatment in the Netherlands during 1996-2005. Affect Disord 2008, 111:94-99.

143. Kovacs G: Pharmacotherapeutic trends at the beginning of the millennium in Hungary. Pharmacotherapy for bipolar patients, I. [in Hungarian]. Neuropsychopharmacol Hung 2004, 6:13-18.

144. Lloyd AJ, Harrison CL, Ferrier IN, Young AH: The pharmacological treatment of bipolar affective disorder: practice is improving but could still be better. J Psychopharmacol 2003, 17:230-233.

doi:10.1186/1744-859X-10-8

Cite this article as: Fountoulakis et al: Class effect of pharmacotherapy in bipolar disorder: fact or misbelief? Annals of General Psychiatry 2011 $10: 8$

\section{Submit your next manuscript to BioMed Central and take full advantage of:}

- Convenient online submission

- Thorough peer review

- No space constraints or color figure charges

- Immediate publication on acceptance

- Inclusion in PubMed, CAS, Scopus and Google Scholar

- Research which is freely available for redistribution

Submit your manuscript at www.biomedcentral.com/submit
C) Biomed Central 